\title{
Festival Katılımcısı İşletmelerin Algılanan Toplumsal Fayda, Algılanan Toplumsal Maliyet ve Katılım Motivasyonlarının Festival Memnuniyeti ve Sadakati Üzerindeki Etkisi
}

\author{
DOI: 10.26466/opus.815382 \\ $*$

\begin{abstract}
Orhan Duman* - Sertaç Ercan ** - Burak Yaprak ***
${ }^{*}$ Dr. Öğr. Üyesi, Bandırma Onyedi Eylül Üniversitesi

E-Posta: oduman@bandirma.edu.tr

ORCID: $\quad \underline{0000-0002-8983-5949}$

** Öğr. Gör., Bandırma Onyedi Eylül Üniversitesi

E-Posta: sercan@bandirma.edu.tr

ORCID: $\underline{\text { 0000-0003-3896-9194 }}$

*** Arş. Gör., Bandırma Onyedi Eylül Üniversitesi

E-Posta: byaprak@bandirma.edu.tr

ORCID: $\underline{0000-0001-9831-0813}$
\end{abstract}

\begin{abstract}
Öz
Turizm pazarlaması ve yönetim faaliyeti olan festivaller, festivalin düzenlendiğ i destinasyonlara olumlu katkılar sağlamayı hedefleyen ekonomik, sosyal ve kültürrel etkinliklerdir. Bu çalışmada 2019 yılında ilki gerçekleştirilen Gönen Alıveriş Festivali örnek olay olarak ele alınmış, festivallerin toplumsal faydalar ve toplumsal maliyetleri ile paydaşlarn festivale katılma motivasyonlarl, festivalden memnuniyet ve sadakat düzeylerinin belirlenmesi amaçlanmıştır. Bu amaç doğrultusunda festival paydaşlarından 105 adet işletmeyle yüz yüze ve ana kütlenin tamamına ulaşılarak tamsayım anket yöntemiyle kullanılmıştır. Araştırmanın amacına uygun olarak kurulan araştırma modeli ve gerçekleştirilen istatistiki analiz sonuçlarına göre, toplumsal fayda değişkeninin memnuniyet üzerinde olumlu bir etkisi olduğu; toplumsal maliyet ve motivasyon değişkenlerinin ise memnuniyet üzerinde istatistiki açından anlamlı bir etkisinin olmadı̆̆ı görülmüş̧ür. Ayrıca toplumsal fayda ve motivasyon değişkenlerinin sadakat üzerinde olumlu, toplumsal maliyet değişkeninin ise sadakat üzerinde olumsuz bir etkisinin olduğu sonucuna varılmıştır. Çalışmanın, gelecekte organize edilecek çeşitli festival ve etkinliklere, belirtilen değişkenler çerçevesinde çizdiği yol haritasıyla rehberlik etmesi, turizm, pazarlama ve halkla ilişkiler faaliyetleriyle ilişkili literatüre katkı sağlaması hedeflenmektedir.
\end{abstract}

Anahtar Kelimeler: turizm, festival, toplumsal fayda, toplumsal maliyet, katilım motivasyonu 
ISSN: 2528-9527

E-ISSN : 2528-9535

Yıl Year: 11

Cilt Volume: 17

Sayı Issue: 35

Mart March 2021

Makalenin Geliş Tarihi Received Date. 26/10/2020

Makalenin Kabul Tarihi Accepted Date. 17/03/2021

\title{
Examining the Effects of Perceived Social Benefit, Perceived Social Cost and Participation Motivation in The Festival on Satisfaction and Loyalty
}

\begin{abstract}
Festivals, which are tourism marketing and management activities are economical, social and cultural events aimed at making positive contributions to destinations. In this study, Gönen Shopping Festival, which was held for the first time in 2019, was considered as a sample event, and it was aimed to determine the social benefits and social costs of the festivals, the motivations of the stakeholders to participate in the festival, and the festival satisfaction and festival. For this purpose, face-to-face and complete count were conducted with 105 companies that are the stakeholders of the festival. According to the research model established in accordance with the purpose and the statistical analysis results, the social benefit variable has a positive effect on satisfaction, while the social cost and motivation variables have no statistically significant effect on satisfaction. In addition, it was concluded that social benefit and motivation variables have a positive effect on loyalty, and social cost variables have a negative effect on loyalty. It is aimed that the study will guide the festivals to be organized in the future with the road map drawn within the framework of the specified variables and will contribute to the literature related to tourism and marketing activities.
\end{abstract}

Keywords: tourism, festival, social benefit, social cost, participation motivation. 


\section{Giriş}

Bir turizm faaliyeti olarak festivaller, bir destinasyonun başarılı bir şekilde ev sahipliği yapabilmesini mümkün kılan kültürel kaynaklardır faaliyetlerdir. (Getz, 2005). Bu faaliyet türünün yerel halk üzerinde ekonomik olarak etkileri bulunsa da göz ardı edilen sosyo-kültürel etkileri de bulunmaktadır (O'Sullivan ve Jackson, 2002). Bunlar, toplumsal uyum (Yolal vd., 2009), grup/aile birlikteliği (Kim vd., 2006; Yolal vd., 2012), sosyalleşme (Saayman vd., 2012) ve eğlence (Báez ve Devesa, 2014) olarak sıralanabilir. Bunlarla birlikte festivaller bazı olumsuz etkileri en aza indirgeyebilir, sürdürülebilir kalkınmaya katkıda bulunabilir, ev sahibi ve ziyaretçi ilişkisini geliştirebilir ve sosyo-kültürel çevrenin korunmasına yardımcı olabilir (Uysal vd., 1993).

Literatürde festivalleri farklı açılardan inceleyen çalışmalar yer almaktadır. Woosnam vd. (2013) tarafından gerçekleştirilen araştırmada festivale katılanların toplumsal fayda, bireysel fayda ve sosyal maliyet unsurların kapsayan festivalin etkisine yönelik algılarındaki farklılık olup olmadığı incelenmiştir. Bu araştırmada katılımcıların sosyo-demografik ve sosyo-ekonomik özelliklerinin festivale ilişkin algılanan toplumsal fayda üzerinde önemli bir etkisi olduğu bulunmuştur. Yine Grunwell (2007)'in gerçekleştirdiği araştırmaya göre konaklayan ziyaretçiler günü birlik ziyaretçilere oranla daha fazla harcama yaparak yerel ekonomiye katkı sağlamaktadır. Gerçekleştirilen araştırmada ilk yıl festivalden memnun olduğunu ve gelecek yıl tekrar kattlacağını ifade edenlerin yalnızca üçte birinin ikinci yıl düzenlenen festivale katılım gösterdiği sonucuna ulaşılmıştır. Bu açıdan ilk yıl düzenlenen festivallerde önemli noktaların tespit edilerek katılımcılardan geri bildirim alınması gelecek organizasyonların başarısı için önemli olduğu vurgulanmaktadır. Festivallerin etkilerine yönelik gerçekleştirilen farklı araştırmalarda genel olarak konuyu bir etkinliğe ev sahipliği yapmanın ekonomik açıdan finansal bir kazanç veya kayıp olarak ele aldığı görülmektedir (Getz, 2005). Bunlarla birlikte geleneksel çalışmalarda festival ve etkinliklerin çıtıları değerlendirilirken ekonomik etkiler araştırılmakta, festivallerin sosyo-kültürel etkileri çoğunlukla ikincil olarak ele alınmaktadır (Fredline vd., 2005).

Organizatörlerin festivallerin ve özel etkinliklerin sosyo-ekonomik etkilerine yönelik algıları dört boyut altında incelenebilmektedir. Bunlar toplumsal uyum, ekonomik faydalar, sosyal teşvikler ve sosyal maliyetler olarak sırala- 
nabilmektedir (Gursoy vd., 2004). Literatürdeki bilgiler ışığında bu çalışmada, 21-22-23 Kasım 2019 tarihlerinde Balıkesir ilinin Gönen ilçesinde Gönen Ticaret Odası tarafından düzenlenen Gönen Alışveriş Festivali toplumsal fayda, toplumsal maliyet, memnuniyet ve sadakat kavramları kapsamında incelenmiştir.

Bu çalışmanın temel amacı yerel yönetimler, sivil toplum kuruluşları veya diğer kurum ve kuruluşlar tarafından ilgili destinasyonun tanıtımını yapmak, finansal fayda yaratmak ve kültürel etkileşimi artırmak gibi amaçlarla düzenlenen festivallerin sosyal ve ekonomik etkilerini ortaya koymaktır. $\mathrm{Bu}$ temel amacin yanında festivallerin toplumsal faydaları, toplumsal maliyetleri ve paydaşların festivale katılma motivasyonları ile paydaşların festivalden memnuniyet ve sadakat düzeylerinin belirlenmesi de diğer alt amaçları oluşturmaktadır.

Araştırma amacına uygun olarak kurulan araştırma modeli çerçevesinde belirlenen hipotezler çeşitli istatistiki analizlere tabi tutulmuştur. Analiz sonuçlarına bakıldığında toplumsal fayda değişkeninin memnuniyet üzerinde olumlu bir etkisi bulunurken toplumsal maliyet ve motivasyon değişkenlerinin ise memnuniyet üzerinde istatistiki açından bir etkisinin olmadığı görülmüştür. Ayrıca toplumsal fayda ve motivasyon değişkenlerinin sadakat üzerinde istatistiki olarak olumlu, toplumsal maliyet değişkeninin sadakat üzerinde olumsuz bir etkisinin olduğu sonucuna varılmıştır.

\section{Kav. Çerçeve Literatür Taraması ve Hipotezlerin Geliştirilmesi}

\section{Toplumsal Fayda}

Pek çok çalışma festivallerin toplumdaki yaşam kalitesini arttırdığını göstermektedir (Attanasi vd., 2013; Besculides vd., 2002; Yolal vd., 2016). Festival gibi turizm faaliyetleri topluma, "toplumsal fayda" bağlamında birçok aç1dan katkıda bulunmaktadır. Bu katkılardan bazıları, gelir düzeyi ve vergi gelirlerinde artış, sağladığı iş fırsatları, ekonomik çeşitlilik, sosyal, kültürel ve çevresel zenginlik sayesinde yerel halkın yaşam standartlarının gelişimi ile toplumun yaşam kalitelerini arttırma olarak sıralanabilir (Andereck vd., 2005).

Festivaller, toplumsal imaj oluşturulmasına olumlu katkıda bulunur. Aynı zamanda durağan olan cazibe merkezlerine hareketlilik kazandırılması sebe- 
biyle sosyo-kültürel gelişmelerde katalizör rolü oynamaktadır. Böylelikle katılımc1, yatırımcı ve sponsorları cezbeden bir yapıya sahiptir (Getz, 1993; Quinn, 2006). Özetle Dolayısıyla festivallerin sağladığı toplumsal fayda sadece katılımcı ve yerel halk tarafından değil organizatörler, sponsorlar, yatırımc1lar ve paydaşlar tarafından da algılanan önemli bir faktördür. Belirtilen faydaların yanında festivallerin, turizm sezonlarının sürelerini uzatması sebebiyle mevsimselliğin etkisini azaltıcı bir etki oluşturması, toplumsal canlanma ve birliktelik için firsatlar sağlaması, onları desteklemesi ve uyumunu arttırıcı bir etki oluşturması, yerel halk ile ziyaretçiler arasında hoşgörü ve anlayışın gelişimine katkı sağlaması, katılımcılar açısından eğitici ve kültürel fırsatlar sağlamanın yanı sıra toplumsal gurur hissini arttırması, doğal ve kültürel çevrenin korunmasına yardımcı olması gibi birçok faydasından da bahsedilebilir (Allen vd., 2012; Arcodia ve Whitford, 2007; Attanasi vd., 2013; Backman vd., 1995; Besculides vd., 2002; Ferdinand ve Williams, 2013; Gursoy vd., 2004).

Yukarıda ifade edildiği gibi "toplumsal fayda" kavramı festivallerin paydaş, katılımcı, organizatör, sponsor gibi farklı tarafların algıladığı değerlerle ilgilidir. Bu çalışmada ise paydaşların gözünden ve incelenen festival kapsamında "algilanan toplumsal fayda" bağımsız bir değişken olarak ele alınmakta, "memnuniyet" $\left(\mathbf{H}_{1}\right)$ ve "sadakat" $\left(\mathbf{H}_{4}\right)$ bağımlı değişkenleri kavramları üzerindeki etkisi incelenmektedir.

- Hı: Toplumsal fayda değişkeninin memnuniyet üzerinde pozitif yönlü ve anlamlı bir etkisi bulunmaktadır.

- $\quad H_{4}$ : Toplumsal fayda değişkeninin sadakat üzerinde pozitif yönlü ve anlamlı bir etkisi bulunmaktadır.

\section{Toplumsal Maliyet}

Etkinlik turizmi kapsamında gerçekleştirilen bir festivale (destinasyon) birçok turist ve katılımcı gelmesi beklenir. Gelen bu ziyaretçi ve katılımcıların sayısının çok olması o etkinliğe olan ilgiyi göstermekte ve organizatörler aç1sından sayının yüksek olması beklenmektedir. Beklenti böyle olmakla birlikte gelen ziyaretçiler açısından elde edilen faydaların yanında bazı maliyetler de dikkat edilmesi gereken önemli hususlar arasındadır. Ziyaretçilerin bir destinasyona ulaşmasında öncelikle dikkat edilecek nokta ulaşım altyapısıdır. Festivallere ve etkinliklere bağlı olarak ulaşım altyapısı geliştikçe, ulaşım 
yollarından kaynaklanan kirlilik ve çevreye olan doğrudan zararlar da artmaktadır (Gossling, 2002, s. 288).

Festival bölgelerinde, fiziksel ve çevresel kirlilikte artışların olacağı, ayrıca müzik festivallerinde bu sorunlara gürültü kirliliğinin de eklenmektedir. Festivaller, göze hoş gelmeyen kamp alanları ve diğer kısa vadeli yapılar gibi estetik değişiklikleri içerebilir (Yeoman vd., 2012, s.317). Festival nedeniyle bir bölgeye birçok ziyaretçinin gelmesi yerel hizmetlerde ekstra talep oluşturacak ve çeşitli aksamalara sebep olacaktır. Bunlara, trafik sıkışıklığı ve kazaları, vandalizm, yangın ihtimali, çevresel bozulma ve atıkların (çöp vb.) artması örnek olarak verilebilir. Bunu yanında, perakende ve restoran işletmelerinde artan fiyatlar, kalabalık ve oluşan sıralar ve yerel sakinler açısından yaşam tarzlarının bozulması gibi maddeler eklenebilir (Crompton, 1995).

Ayrıca, dışarıdan gelen sanatçı ve grupların bölgenin korunmuş kültürel iklimine olumsuz etkiler yapacağı ve yabancı kültürün bölgeye nüfuz etmesini kolaylaştıracağı değerlendirilmektedir. Bölgedeki yerel ziyaretçi ve kattlımcılar açısından bu tür etkinlikler riskli olarak görülebilmektedir. Söz gelimi festival özellikle yabancı ziyaretçileri hedeflemiyorsa yerel kültürel değerler ve sanatlar da en az yabancı kültürel değerler ve sanatlar kadar öne çıkmalıdır. (Carlsen vd., 2007, s.5).

"Toplumsal maliyet" kavramı "toplumsal fayda" kavramının aksine olumsuz olarak algılanan bir unsurdur. Aynı "toplumsal fayda" değişkeninde olduğu gibi paydaşların tarafından algılanan "toplumsal maliyet" de bağımsız bir değişken olarak ele alınmakta, "memnuniyet" $\left(\mathbf{H}_{2}\right)$ ve "sadakat" (H) kavramları üzerindeki etkisi incelenmektedir.

- $\quad H_{2}$ : Toplumsal maliyet değişkeninin memnuniyet üzerinde negatif yönlü ve anlamlı bir etkisi bulunmaktadır.

- H5: Toplumsal maliyet değişkeninin sadakat üzerinde negatif yönlü ve anlamlı bir etkisi bulunmaktadır.

\section{Motivasyon}

Motivasyon, tüketicilerin davranış ve faaliyetlerini canlandıran, yönlendirip bütünleştiren psikolojik ve fizyolojik ihtiyaç ve isteklerdir (Kozak, 2002, s.224). Festival organizatörleri ve paydaşları çeşitli motivasyonlar gözeterek festival ve etkinliklere katılım göstermektedirler. Bunlar, ekonomik etkiler, 
topluma dair olumlu etkiler, kişisel etkiler ve yaşam kalitesine etkiler olarak incelenebilir.

Etkinlik turizminin ekonomik etkileri incelendiğinde, bir bölgedeki özel sektör, kamu ve halk olmak üzere tüm paydaşlar açısından önemi ortaya çıkmaktadır. Festivaller, bir destinasyonun ekonomik gelişiminde hem doğrudan hem de dışardan gelen yeni paranın ekonomiye girmesinden ortaya çıkan dolaylı etkiler sağlamaktadır. Bu açıdan etkinlik turizmi, özellikle kırsal alanlarda giderek daha popüler hale gelmektedir. Festivaller bölgelerin, ekonomik olarak zenginleşmesi ve yapılanması, kültürel ve el sanatları aracıllğıyla kültürel yenilenmesi, beşerî sermayeyi ve kültürel kaynakları geliştirmesi, yaşam kalitesini, iş ve vergi gelirlerini arttırması gibi başka olumlu katkıları da bulunmaktadır (Irshad, 2011). Festivallerle bölgeye gelen ziyaretçiler, destinasyonlara fazladan para girişi sağlayarak ve ekonomik hareketlenme artş̧ından oluşan üretim ve istihdam sebebiyle kent ve bölge ekonomilerine olumlu katkılar yapmaktadır (Walo vd., 1996, s.7).

"Motivasyon" kavramı paydaşların festivale bakış açısını gösteren önemli bir göstergedir. Çalı̧̧mada "motivasyon" kavramının bağımsız bir değişken olarak "memnuniyet" $\left(\mathbf{H}_{3}\right)$ ve "sadakat" $\left(\mathbf{H}_{6}\right)$ kavramları üzerindeki etkisi incelenmektedir.

- $\quad \mathbf{H}_{3}$ : Motivasyon değişkeninin memnuniyet üzerinde pozitif yönlü ve anlamlı bir etkisi bulunmaktadır.

- H6: Motivasyon değişkeninin sadakat üzerinde pozitif yönlü ve anlamlı bir etkisi bulunmaktadır.

\section{Memnuniyet}

Festival ve etkinliklerin gerçekleştirilmesinde birçok paydaş bulunmaktadır. Etkinliklerde görev alan kişi, grup ve kurumların hepsi paydaş olarak değerlendirilmektedir (Polat, 2012, s.36). Paydaşların memnuniyeti, genel olarak etkinliğe katılımları sayesinde elde ettikleri tecrübelerinin genel bir değerlendirmesidir (Lee ve Back, 2008, s.332).

Festival paydaşların katılımını artırmak için, festival düzenleyicilerinin festival katılımcılarının yaşanan deneyimlere bağlı olarak paydaş memnuniyetini izlemek ve değerlendirmesi önemlidir. Katılımcıların ihtiyaçlarını anlamak ve belirlemek, düzenleyicilerin festivali paydaşlara göre tasarlama ve uyarlamalarını sağlayarak paydaş memnuniyetini artırmalarını sağlar (Lee 
vd., 2011, s. 688). Paydaşların memnuniyeti açısından algılanan değer önemlidir. Algılanan değerin, ürün veya hizmet performansına dayanan kullanım deneyimine bağlıdır (Graf ve Maas, 2008, s.8).

Paydaşların beklentileri, memnuniyet düzeylerini belirlemede etkili olmaktadır. Festival paydaşlarının o festivalden beklentileri, festival performansını değerlendirmeleriyle ortaya çımaktadır. Eğer paydaşlar festivali beklentisinin üzerinde görürse olumlu bir değerlendirme, performansı beklentisinin altında görürse olumsuz bir değerlendirme yapacaktır. (Oliver, 1980). Paydaşların memnuniyeti, vazgeçtikleri kaynaklar ve elde etmeyi bekledikleri sonuç ve faydalara göre değerlendirilmesidir. Paydaşların emek, zaman ve nakit harcamaları karşılığında elde ettikleri faydalar yüksek olursa bu festival memnuniyet verici olarak algilanabilir (Sasser vd., 1997).

Çalışmada "memnuniyet" kavramı bağımlı bir değişken olarak toplumsal fayda, toplumsal maliyet ve motivasyon unsurlarıyla etkileşimi incelenmektedir $\left(\mathbf{H}_{1}, \mathbf{H}_{2}, \mathbf{H}_{3}\right)$. Ayrıca çalışmada diğer bağımlı değişken "sadakat" $\left.\mathbf{( H}_{7}\right)$ kavramıla olan etkileşimi de diğer inceleme konusudur.

H7: Memnuniyet değişkeninin sadakat üzerinde pozitif yönlü ve anlamlı bir etkisi bulunmaktadır.

\section{Metodoloji}

\section{Araştırmanın Amacı ve Kapsamı}

Yerel yönetimler, sivil toplum kuruluşları veya diğer kurum ve kuruluşlar tarafından ilgili destinasyonun tanıtımını yapmak, finansal fayda yaratmak ve kültürel etkileşimi artırmak gibi amaçlarla düzenlenen festivallerin sosyal ve ekonomik etkileri bütün paydaşlar açısından oldukça önem taşımaktadır. Çalışma kapsamında festivallerin toplumsal faydaları, toplumsal maliyetleri ve paydaşların festivale katılma motivasyonları ile paydaşların festivalden memnuniyet ve sadakat düzeylerinin belirlenmesi amaçlanmaktadır. 
Araştırmanın Kavramsal Modeli ve Hipotezler

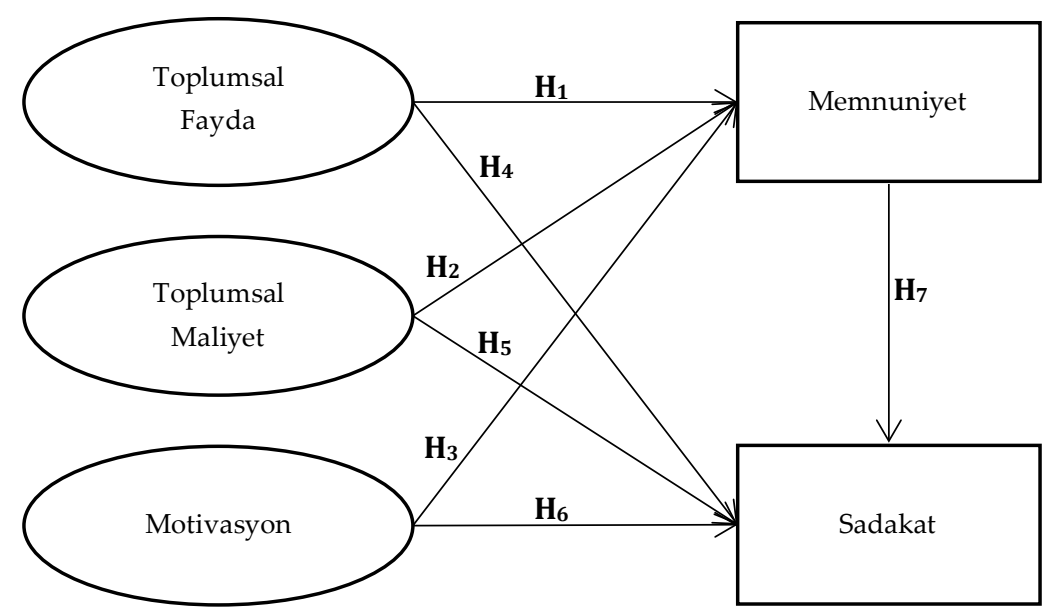

Şekil 1. Araştırma Modeli

\section{Örneklemin Belirlenmesi ve Verilerin Toplanması}

Çalışmanın evrenini 21-22-23 Kasım 2019 tarihlerinde Balıkesir' in Gönen ilçesinde gerçekleştirilen alışveriş festivalinin düzenlendiği kent merkezinde, festival alanının çevresinde yer alan çeşitli sektörlerden işletmeler oluşturmaktadır. Bir anket uygulamasının veya benzer tekniklerin araştırma evrenini oluşturan tüm birimlere uygulanması durumunda tam sayım anketi söz konusudur (Dura, 2005, s. 108). Bu çalışmanın örneklemini festivalin organizatörlüğünü üstlenen Gönen Ticaret Odası'nın yönlendirmesi üzerine toplamda 105 işletme oluşturmaktadır. Bu işletmelere festival sonrasında 29-30 Kasım 2019 tarihlerinde festivalin paydaşı olan bütün işletmelere ulaşılmış ve yüz yüze anket yöntemiyle tam sayımanket uygulanmıştır.

\section{Ölçeklerin Belirlenmesi}

Çalışma kapsamında beş ölçek kullanılmaktadır. Bunlar toplumsal fayda ölçeği, toplumsal maliyet ölçeği, motivasyon ölçeği, memnuniyet ölçeği ve sadakat ölçeğidir. Araştırmada kullanılan toplumsal fayda ve toplumsal mali- 
yet ölçekleri, Delamere vd. (2001) ve Delamere (2001) tarafından iki ayrı çalışmada geliştirilen ölçekler çeviri-geri çeviri çapraz çeviri yapılarak dilimize adapte edilmiştir. Motivasyon ölçeği ise Kozak (2005) tarafından "stratejik fayda ve satıs", "rekabet ve araştırma" ve "promosyon" şeklinde üç boyutlu olarak hazırlanan ölçek adapte edilerek kullanılmıştır. Kozak (2005) tarafından kullanılan üç boyuttan yalnızca stratejik fayda ve satış boyutu bu çalı̧̧maya dahil edilmiştir. Çalışmanın bağımlı değişkenlerinden birisi olan memnuniyet düzeyini ölçmek için kullanılan ölçek, Lee ve Beeler (2006) tarafından kullanılan ölçekten uyarlanmıştır. adapte edilmiştir. Sadakat değişkenini ölçmek için ise Yoon vd. (2010) tarafından kullanılan ölçek adapte edilerek uyarlanarak kullanılmıştır. Araştırmada kullanılan ölçekler 5'li Likert tipidir. Buna göre seçenekler 1-Kesinlikle Katılmıyorum, 2-Katılmıyorum, 3- Ne Katılıyorum Ne Katılmıyorum, 4-Katılıyorum ve 5- Kesinlikle Katılıyorum şeklinde sıralanmaktadır.

\section{Bulgular}

\section{Betimleyici İstatistikler}

Araştırma kapsamında, anket yoluyla verilerin toplandığ 1 işletmelere ait betimleyici istatistikler Tablo 1'de gösterilmektedir.

\section{Tablo 1. Betimleyici İstatistikler}

\begin{tabular}{llllll}
\hline Personel Sayısı & \multicolumn{5}{l}{ Faaliyet Yılı } \\
\hline Sayı & Frekans & Yüzde (\%) & Yıl & Frekans & Yüzde (\%) \\
\hline $\mathbf{1}$ kişi & 29 & $\% 27,6$ & $\mathbf{1 - 5}$ arası & 28 & $\% 26,7$ \\
\hline $\mathbf{2}$ kişi & 36 & $\% 34,3$ & $\mathbf{6 - 1 0}$ arası & 19 & $\% 20,9$ \\
\hline $\mathbf{3}$ kişi & 10 & $\% 9,5$ & $\mathbf{1 1 - 1 5}$ arası & 13 & $\% 12,4$ \\
\hline $\mathbf{4}$ kişi & 11 & $\% 10,5$ & $\mathbf{1 6 - 2 0}$ arası & 14 & $\% 13,3$ \\
\hline $\mathbf{5}$ kişi & 3 & $\% 2,9$ & $\mathbf{2 1 - 2 5}$ arası & 8 & $\% 8,5$ \\
\hline 6+ kişi & 16 & $\% 14,3$ & $\mathbf{2 5 +}$ & 12 & $\% 18,2$ \\
\hline Toplam & 105 & $\% 100$ & Toplam & 105 & $\% 100$ \\
\hline
\end{tabular}

Tablo 1'e göre, anket formuna cevap veren işletmelerin \%27,6'sında (29 işletme) bir kişi, \%34,3'ünde (36 işletme) iki kişi, \%9,5' inde (10 işletme) ise üç kişi çalışmaktadır. Böylece cevaplayıcı işletmelerin toplam \%71,4'ü (75 işletme) mikro işletme olarak tanımlanabilir. Bu işletmelerin dışında, çalışmaya katılan işletmelerin \%10,5'i (11 işletme) dört kişi, \%2,9'u (3 işletme) beş kişi, $\% 14,3$ '̈ü (16 işletme) de altı ya da daha fazla kişiyle işletilmektedir. 
Bu işletmelerin faaliyet yıllarına bakıldığında, \%26,7'si (28 işletme) 1-5 yıl, \%20,9'u (19 işletme) 6-10 yıl, \%12,4'ü (13 işletme) 11-15 yıl, \%13,3’ü (14 işletme) $16-20$ yıl, \%8,5'i (8 işletme) 21-25 yıl ve son olarak \%18,2'si (12 işletme) 25 yıldan fazla süredir faaliyetlerine devam ettiği görülmektedir. Bu veriler ışığında cevaplayıcı işletmelerin büyük çoğunluğunun bölgenin eski işletmeleri olduğu görülmektedir. göstermektedir. Cevaplayıcıların festival hakkındaki genel tutumları Tablo 2' de yer almaktadır.

Tablo 2. Cevaplayıcilarn Festival Hakkında Genel Tutumlan

\begin{tabular}{lll}
\hline \multicolumn{2}{l}{$\mathbf{1}=$ Hiç Tatmin Edici Değil - 10=Oldukça Tatmin Edici) } & \\
\hline Sıra & İfadeler & Ortalama \\
\hline $\mathbf{1 .}$ & Festivale çevre il ve ilçelerden gelen katılımcı sayısı & 6,39 \\
\hline $\mathbf{2 .}$ & Festivalin satışları artırma düzeyi & 5,47 \\
\hline $\mathbf{( 1 = O l d u k c ̧ a ~ Y e t e r s i z ~ - ~ 1 0 = O l d u k c ̧ a ~ Y e t e r l i ) ~}$ & Ortalama \\
\hline & İfadeler & 6,97 \\
\hline $\mathbf{3 .}$ & Festivalde alınan güvenlik önlemleri & 7,15 \\
\hline $\mathbf{4 .}$ & Festivalde kullanılan sahne ve ekipmanlar & 7,14 \\
\hline $\mathbf{5 .}$ & Festivalde çalışan personeller & 6,53 \\
\hline $\mathbf{6 .}$ & Festivalin tanıtımı hususunda sosyal medya kullanımı & 5,51 \\
\hline $\mathbf{7 .}$ & Festivalin tanıtımı hususunda yerel medya kullanımı & 2,82 \\
\hline $\mathbf{8 .}$ & Festivalin tanıtımı hususunda ulusal medya kullanımı & \\
\hline
\end{tabular}

Tablo 2 cevaplayıcıların festival hakkındaki genel tutumlarını dair ifadeleri içermektedir. 1. ifadenin ortalamasına bakıldığında $(6,29)$ cevaplayıcıların çevre il ve ilçelerden gelen katılımcı sayısının tatmin edici düzeye yakın olduğunu düşündükleri belirtilebilir. Bu ifade sonucuna göre sonraki festivallerde katılımcı sayısını daha fazla arttırmaya yönelik çalışmalar yapılması uygun olacağını söylenebilir 2. ifade olan festivalin satış artırma düzeyine verilen cevaplar ise 5,47 ortalama ile ne tatmin edici ne de tatminsizlik oluşturan bir seviyede olmadığını göstermektedir. Bu sonuç, paydaşlar açısından en önde gelen festivale katılma sebeplerinden olan satış arttırma konusunun sonraki festivallerde dikkat edilmesi gereken bir durum olarak ortaya çımaktadır. Festivaldeki güvenlik önlemleriyle ilgili olan 3. ifadenin ortalaması ise 6,97'dir. Bu da paydaşların güvenlik önlemlerini genel olarak yeterli gördüğünü göstermektedir. 4 . ifade ve 5. ifadeye göre verilen cevaplara göre festivalde kullanılan sahne ve ekipmanların $(7,15)$ ve festivalde çalışan personelin $(7,14)$ yüksek oranda yeterli olduğu görülmektedir. 6., 7. ve 8. ifadelerdeki medya kullanımıyla ilgili sorulan soruya sorulara verilen cevaplarda ise, sosyal medya kullanımının $(6,53)$ yeterli düzeye yakın, yerel medya kullanımının $(5,51)$ ne yeterli ne yetersiz bir seviyede, ulusal medya kullanımın ise 
$(2,82)$ yetersiz seviyede olduğu tespit edilmiştir. Medya kullanımıyla ilgili bulgulara göre sonraki festivallerde medya kullanımı konusuna daha fazla önem gösterilmesi, özellikle ulusal medyanın kullanımı konusunda çalışmaların arttırılması gerektiği ön plana çıkmaktadır.

\section{Kullanılan Ölçekler ve Ölçeklere Ait İstatistikler}

Güvenilirlik: Araştırmanın farklı zaman ve koşullarda tekrarlanması halinde aynı sonuçları gösterip göstermeyeceğini gösteren bir kavram olan güvenilirlik, koşullar değişmedikçe katılımcıların aynı seviyede tutum sergileyip sergilemeyeceğinin temel göstergesidir (Gegez, 2010, s.185). Ölçeklerin güvenilirlik seviyesini test etmek için kullanılan katsayılardan yaygın olarak kullanılanı Cronbach's Alpha'dır. Bu katsayı ölçekte yer alan değişkenlerin homojenliğini göstermektedir. Bu katsayı, her bir ölçek için 0 ile 1,00 arasında bir değer almaktadır. Cronbach's Alpha katsayısının alabileceği değer aralıkları ve bu aralıkların güven düzeyleri

- Gösterilmektedir (Hair vd., 2000: 391):

- $0,00 \leq \alpha<0,40$ ise ölçek güvenilir değildir.

- $0,40 \leq \alpha<0,60$ ise ölçeğin güvenilirliği düşüktür.

- $0,60 \leq \alpha<0,80$ ise ölçek oldukça güvenilirdir.

- $\quad 0,80 \leq \alpha<1,00$ ise ölçek yüksek derecede güvenilirdir.

Tablo 3'te araştırmada kullanılan ölçeklere ait güvenilirlik katsayıları görünmektedir.

Tablo 3. Ölçeklere Ait Güvenilirlik Katsayıları

\begin{tabular}{lll}
\hline Ölçek & Değişken Sayısı & Cronbach's Alpha \\
\hline Toplumsal Fayda & 13 & 0,905 \\
\hline Toplumsal Maliyet & 14 & 0,822 \\
\hline Memnuniyet & 3 & 0,804 \\
\hline Sadakat & 3 & 0,891 \\
\hline Motivasyon & 8 & 0,969 \\
\hline
\end{tabular}

Araştırmada kullanılan ölçeklere ait güvenilirlik katsayısı olan Cronbach's Alpha katsayıları incelendiğinde tüm ölçeklere ait katsayıların 0,80 seviyesinin üzerinde değerler aldığı görülmektedir. Sonuç olarak, araştırmada kullanılan ölçeklerin tamamı yüksek derecede güvenilirdir. 


\section{Ölçeklere Ait Tanımlayıcı İstatistikler}

Tablo 4'te toplumsal fayda ölçeğine ait tanımlayıcı istatistikler gösterilmektedir.

Tablo 4. Toplumsal Fayda Ölçeğine Ait İstatistikler

\begin{tabular}{|c|c|c|}
\hline \multicolumn{3}{|c|}{ Toplumsal Fayda (Delamere vd., 2001; Delamere, 2001) } \\
\hline \multicolumn{3}{|c|}{ (1=Kesinlikle Katılmıyorum - 5=Kesinlikle Katılıyorum) } \\
\hline Kisaltma & İfadeler & Ortalama \\
\hline TOF1 & $\begin{array}{l}\text { Festivalin, kentimizin birlik ve beraberliğine katkıda bulunduğunu düşü- } \\
\text { nüyorum. }\end{array}$ & 3,76 \\
\hline TOF2 & $\begin{array}{l}\text { Kentimiz dışından katılımcıların festivale gelmesinin kentimiz açısından } \\
\text { genel olarak olumlu bir durum olduğunu düşünüyorum. }\end{array}$ & 3,95 \\
\hline TOF3 & $\begin{array}{l}\text { Festival süresince kentimizde sosyal etkileşim için normal zamandan } \\
\text { daha fazla fırsat olduğunu düşünüyorum. }\end{array}$ & 3,89 \\
\hline TOF4 & Kentimizin festivali sahiplendiğini düşünüyorum. & 3,64 \\
\hline TOF5 & Festivalin, kentimizin tanıtımına olumlu katkısı olduğu görüşündeyim. & 3,84 \\
\hline TOF6 & $\begin{array}{l}\text { Kentimizde her birey ve her kurumun festivalin hedefleri doğrultusunda } \\
\text { iş birliği yaptığını düşünüyorum. }\end{array}$ & 3,37 \\
\hline TOF7 & Festivalin kentimize bir kimlik kazandırdığını düşünüyorum. & 3,86 \\
\hline TOF8 & $\begin{array}{l}\text { Festivalin diğer kentler karşısında kentimiz için bir övünç vesilesi oldu- } \\
\text { ğunu düşünüyorum. }\end{array}$ & 3,85 \\
\hline TOF9 & $\begin{array}{l}\text { Festivalin, kentimizdeki işletmelerin kendini tanıtmasına imkân sağladı- } \\
\text { ğını düşünüyorum. }\end{array}$ & 3,76 \\
\hline TOF10 & $\begin{array}{l}\text { Festivalin kentimizde halen devam eden olumlu bir kültürel etki bıraktı- } \\
\text { ğını düşünüyorum. }\end{array}$ & 3,46 \\
\hline TOF11 & $\begin{array}{l}\text { Festivalin kentimize çeşitli etkinlik seçenekleri sunduğunu düşünüyo- } \\
\text { rum. }\end{array}$ & 3,66 \\
\hline TOF12 & $\begin{array}{l}\text { Festivalin turizm açısından kentimizin imajına olumlu katkıda bulundu- } \\
\text { ğunu düşünüyorum. }\end{array}$ & 3,75 \\
\hline TOF13 & $\begin{array}{l}\text { Festival kapsamında kentimize gelen sanatçı ya da çalışanlarla tanış- } \\
\text { mak/karşılaşmak hoşuma gitti. }\end{array}$ & 3,29 \\
\hline Toplumsa & yda Ölçeği Genel Katılım Ortalaması & 3,69 \\
\hline
\end{tabular}

Toplumsal fayda ölçeğine ait genel katılım ortalaması 3,69'dur. Ölçekte yer alan en yüksek değere sahip değişken 3,95 ortalamaya sahip "Kentimiz dışından katılımcların festivale gelmesinin kentimiz açısından genel olarak olumlu bir durum olduğunu düşünüyorum" ifadesi iken 3,29 katılım ortalamasına sahip "Festival kapsamında kentimize gelen sanatçı ya da çalışanlarla tanışmak/karşılaşmak hoşuma gitti" ifadesidir. Kent dışından gelen katılımcılara ilişkin algılanan faydanın yüksek olması, festivallerin düzenlendiği destinasyona turist çekme ve dolayısıyla ilgili destinasyona çeşitli faydalar sağlayabilme özelliği ile açıklanabilir (Pirnar vd., 2019). Nispi olarak düşük 
yine de 3,00 seviyesinin üzerinde ortalamaya sahip olan sanatçı ve çalışanlarla tanışma değişkeni ise festivallerin sosyo-kültürel faydalarından biri olduğu ifade edilebilir. söylenebilir (Andereck vd., 2005). Toplumsal maliyet ölçeğine ait tanımlayıcı istatistikler Tablo 5'te gösterilmektedir.

\section{Tablo 5. Toplumsal Maliyet Ölçeğine Ait İstatistikler}

\begin{tabular}{|c|c|c|}
\hline \multicolumn{3}{|c|}{ Toplumsal Maliyet (Delamere vd., 2001; Delamere, 2001) } \\
\hline \multicolumn{3}{|c|}{ (1=Kesinlikle Katılmıyorum - 5=Kesinlikle Katılıyorum) } \\
\hline Kisaltma & İfadeler & Ortalama \\
\hline TOM1 & $\begin{array}{l}\text { Festivalin kentimizdeki işletmeler arasında olumsuz seviyede bir rekabet ya- } \\
\text { rattığını düşünüyorum. }\end{array}$ & 2,59 \\
\hline TOM2 & $\begin{array}{l}\text { Festivalin düzenlendiği günlerde kentimizin rahatsız edici seviyede kalabalık } \\
\text { olduğunu düşünüyorum. }\end{array}$ & 2,18 \\
\hline TOM3 & $\begin{array}{l}\text { Festivalin düzenlenmesi için kullanılan finansal kaynağın kentimizdeki başka } \\
\text { projelerde harcanması gerektiği görüşündeyim. }\end{array}$ & 2,71 \\
\hline TOM4 & $\begin{array}{l}\text { Festival esnasında kentimizin rahatsız edici şekilde kullanıldığını (ses ve çevre } \\
\text { kirliliğinin artması, ekolojik hasar oluşturulması vb.) düşünüyorum. }\end{array}$ & 2,20 \\
\hline TOM5 & Festivalin kentimizin imajını zedelediğini düşünüyorum. & 1,86 \\
\hline TOM6 & $\begin{array}{l}\text { Festivale sponsor olmak için az sayıda firmanın istekli olduğunu düşünüyo- } \\
\text { rum. }\end{array}$ & 2,78 \\
\hline TOM7 & Festivalin kentimiz sakinlerinin günlük rutinlerini bozduğunu düşünüyorum. & 2,38 \\
\hline TOM8 & $\begin{array}{l}\text { Festivalin kentimizdeki işletmeler arasındaki anlaşmazlığın artmasına neden } \\
\text { olduğu görüşündeyim. }\end{array}$ & 2,14 \\
\hline TOM9 & Festivaldeki faaliyetlerin kentimizin kimliğini yansıtmadığını düşünüyorum. & 2,60 \\
\hline TOM10 & Festivalin, kentimizin itibarını zedelediğini düşünüyorum. & 1,78 \\
\hline TOM11 & $\begin{array}{l}\text { Festival kapsamında kentimiz dışından gelen insanların kentimizi ahlaki açı- } \\
\text { dan zayıflattığını düşünüyorum. }\end{array}$ & 1.68 \\
\hline TOM12 & $\begin{array}{l}\text { Festival süresince kentimizde araç trafiğinin kabul edilemez seviyede yoğun } \\
\text { olduğunu düşünüyorum. }\end{array}$ & 2,45 \\
\hline TOM13 & $\begin{array}{l}\text { Festival süresince kentimizde yaya trafiğinin kabul edilemez seviyede yoğun } \\
\text { olduğunu düşünüyorum. }\end{array}$ & 2,43 \\
\hline TOM14 & Festival süresince kentimizde suç oranının arttığını düşünüyorum. & 1,76 \\
\hline Toplums & liyet Ölçeği Genel Katılım Ortalaması & 2,25 \\
\hline
\end{tabular}

Toplumsal Maliyet ölçeğinde yer alan tüm değişkenlerin toplam ortalaması 2,25'tir. Anlamca negatif olan bu ifadelerin ortalamalarının 3,00 değerinin altında olması cevaplayıcıların festivalin getirdiği finansal, zaman vb. maliyetlerden rahatsızlık duymadığı sonucuna dayandırılabilir. Ölçekte yer alan değişkenlerin her birine ait katılım ortalamalan incelendiğinde ise katılımın en çok olduğu, dolayısıyla ortalamanın en yüksek olduğu değişkeninin 2,78 ortalama ile "Festivale sponsor olmak için az sayıda firmanın istekli olduğunu düşünüyorum" ifadesi olduğu, en düşük katılım ortalamasının ise 1,76 değerine sahip "Festival süresince kentimizde suç oranının arttığını düşünüyorum" ifadesi olduğu görülmektedir. Cevaplayıcıların festivale katılan ve 
yararlanan işletmeler olduğu düşünüldüğünde sponsorluk isteğine dair bu değişkene nispeten yüksek ortalamaya sahip görüşler belirtmesi işletmelerin, festivale ayrılan bütçe ve verilen desteğin yetersiz olduğu görüşünde oldukları çıkarımı yapılabilir. Suç oranlarının artmasına ilişkin değişkenin katılım ortalamasının en düşük olması ise işletmelerin festival kapsamında yapılan faaliyetler öncesinde, esnasında ve sonrasında alınan güvenlik önlemlerinden memnun oldukları şeklinde açıklanabilir (Kim ve Uysal, 2013). Memnuniyet ölçeğine ait tanımlayıcı istatistikler Tablo 6’ da gösterilmektedir.

Tablo 6. Memnuniyet Ölçeğine Ait İstatistikler

\begin{tabular}{lll}
\hline \multicolumn{2}{l}{ Memnuniyet (Lee and Beeler, 2006) } & \\
\hline (1=Kesinlikle Katılmıyorum - 5=Kesinlikle Katılıyorum) & Ortalama \\
\hline Kısaltma & İfadeler & 3,64 \\
\hline MEM1 & Bir bütün olarak düşündüğümde, festivalde olmak bana mutluluk verdi. & 3,72 \\
\hline MEM2 & Genel olarak festivale katılmaktan tatmin oldum. & 3,85 \\
\hline MEM3 & Genel olarak festivalde elde ettiğim deneyimden memnunum. & 3,73 \\
\hline Memnuniyet Ölçeği Genel Katılım Ortalaması & \\
\hline
\end{tabular}

Memnuniyet ölçeğine ait genel katılım ortalaması 3,73'tür. "Genel olarak festivalde elde ettiğim deneyimden memnunum" ifadesi 3,85 katılım ortalaması ile ölçekte yer alan değişkenler arasında en yüksek ortalamaya sahiptir. En düşük ortalamanın ise 3,64 katılım ortalaması ile "Bir bütün olarak düşündüğümde, festivalde olmak bana mutluluk verdi" değişkenine ait olduğu görülmektedir. Festivaller birer deneyim pazarlaması örneği olduğundan cevaplayıcıların deneyime ilişkin bu değişkene en yüksek ortalamaya sahip tutuma sahip olması geçmiş çalışmaların sonuçlarıyla benzerlik göstermektedir (Anderton, 2011; Yazıcı vd., 2017). Bir bütün olarak festivalden memnuniyet düzeyinin ise nispi olarak düşük olduğu görülmektedir, festival ve organizasyonlar bütüncül hizmetler süreçleri olduğundan sürecin herhangi bir yerinde yaşanan hizmet hatası tüm süreçten duyulan memnuniyet düzeyini (Çalışkan, 2013) etkileyebilmektedir. Tablo 7'de sadakat ölçeğine ait tanımlayıcı istatistikler yer almaktadır.

Tablo 7. Sadakat Ölçeğine Ait İstatistikler

\begin{tabular}{|c|c|c|}
\hline \multicolumn{3}{|c|}{ Sadakat (Lee and Beeler, 2006) } \\
\hline \multicolumn{3}{|c|}{ (1=Kesinlikle Katılmıyorum - 5=Kesinlikle Katılıyorum) } \\
\hline Kisaltma & İfadeler & Ortalama \\
\hline SAD1 & Festival hakkında çevreme olumlu şeyler söyleyeceğim. & 4,03 \\
\hline SAD2 & Gelecekte bu festivale tekrardan katılmayı düşünüyorum. & 4,14 \\
\hline SAD3 & Çevremdekileri festivale katılmaları için teşvik edeceğim. & 3,96 \\
\hline \multicolumn{2}{|c|}{ Sadakat Ölçeği Genel Katılım Ortalaması } & 4,04 \\
\hline
\end{tabular}


Sadakat ölçeğine ait değişkenlerin toplam ortalaması incelendiğinde değerin 4,04 olduğu görülmektedir. Ölçekte yer alan “Gelecekte, bu festivale tekrardan katılmayı düşünüyorum" değişkeni 4,14 katılım ortalaması ile en yüksek değere sahip iken 3,96 katılım ortalaması ile "Çevremdekileri festivale katılmaları içim teşvik edeceğim" değişkeni ise en düşük değere sahiptir. Nispi Göreceli olarak düşük ortalamaya sahip olan çevredekileri teşvik etmeye ilişkin değişken sadakat ve ağızdan ağıza iletişim (Yoo vd., 2013) arasındaki ilişkiyle açıklanabilir, açıklanabilir. Değişkene ait ortalama nispeten düşük olsa da orta nokta olan 3,00'ın oldukça üzerindedir ve kabul edilebilir seviyede yüksektir. Bu değer incelendiğinde bakıldığında ise festivale katılan işletmelerin, festivalin tekrarlanması durumunda katılmayan işletmeleri da teşvik edeceği sonucuna varılabilir. Tablo 8'de motivasyon ölçeğine ait tanımlayıc istatistikler gösterilmektedir.

Tablo 8. Motivasyon Ölçeğine Ait İstatistikler

\begin{tabular}{lll}
\hline \multicolumn{2}{l}{ Motivasyon (Kozak, 2005) } & \\
\hline (1=Kesinlikle Katılmıyorum - 5=Kesinlikle Katılıyorum) & Ortalama \\
\hline Etiket & İfadeler & 3,59 \\
\hline MOT1 & Festivale halkla ilişkiler faaliyetlerini desteklemek için katıldım. & 3,29 \\
\hline MOT2 & Festivale yeni pazarlama tekniklerini deneyimlemek için katıldım. & 3,20 \\
\hline MOT3 & Festivale müşterilerle temas kurmak için katıldım. & 3,20 \\
\hline MOT4 & Festivale müşterilerle ilişkileri geliştirmek için katıldım. & 3,06 \\
\hline MOT5 & Festivale yeni müşterilerle tanışmak için katıldım. & 2,95 \\
\hline MOT6 & Festivale satış siparişleri almak için katıldım. & 3,09 \\
\hline MOT7 & Festivale müşterilerin ihtiyaçları hakkında bilgi elde etmek için katıldım. & 2,98 \\
\hline MOT8 & Festivale yeni ürünlerim için ilgi arttırmak/geliştirmek adına katıldım. & $\mathbf{3 , 1 7}$ \\
\hline Motivasyon Ölçeği Genel Katılım Ortalaması &
\end{tabular}

Cevaplayıcıların motivasyon ölçeğine genel katılım düzeyi 3,17'dir. Ölçekte yer alan ifadelerin her birinin ortalamaları incelendiğinde ise "Festivale halkla ilişkiler faaliyetlerini desteklemek için katıldım" ifadesinin 3,59 ortalama ile en yüksek, "Festivale satış siparişleri almak için katıldım" ifadesinin 2,95 ortalama ile en düşük değere sahip olduğu görülmektedir. Alışveriş festivallerin işletme ve tüketicileri doğrudan buluşturduğu (Chen ve Li, 2020) düşünüldüğünde işletmelerin festivale katılma motivasyonlarından en önemlilerinden birisinin halkla ilişkiler faaliyetleri olduğu ifade edilebilir. Öte yandan festivallerde genellikle gıda, hazır giyim ve turistik ürünler sunulmaktadır, bu ürünler ise genellikle sipariş alma biçiminde değil, doğrudan satış yoluyla (Gale, 1997, s. 21) tüketiciye ulaştırılmaktadır. Böylece, satış 
sipariş almak üzere festivale katılım motivasyonuna ilişkin değişkenin ortalama değerinin nispeten düşük olması temellendirilebilir.

\section{Etki Analizleri}

Araştırma kapsamında toplumsal fayda, toplumsal maliyet ve motivasyon bağımsız değişkenlerinin memnuniyet ve sadakat bağımlı değişkenleri üzerindeki etkisinin yanı sıra memnuniyet değişkeninin sadakat değişkeni üzerindeki etkisi istatistiki açıdan incelenmektedir. Toplumsal fayda, toplumsal maliyet ve motivasyon bağımsız değişkenlerinin memnuniyet bağımlı değişkeni üzerindeki etkisinin hesaplandığı regresyon analizine ait katsayılar Tablo 9'da gösterilmektedir.

Tablo 9. Memnuniyet Bă̆ımlı Değişkenine Ait Çoklu Regresyon Modeli Katsayılan

\begin{tabular}{|c|c|c|c|c|c|c|}
\hline \multicolumn{7}{|c|}{ Model Özeti: $R=0,546 / R^{2}=0,298$ / Düzeltilmiş $R^{2}=0,277 / F=14,308$ / p= 0,00 / Durbin-Watson=1,388 } \\
\hline \multirow{2}{*}{ MODEL } & \multicolumn{2}{|c|}{$\begin{array}{l}\text { Standardize } \\
\text { Edilmemiş Katsayılar }\end{array}$} & \multirow{2}{*}{$\begin{array}{l}\text { Standardize Edilmiş } \\
\text { Katsayılar } \\
\beta \\
\end{array}$} & \multirow[t]{2}{*}{$t$} & \multirow[t]{2}{*}{$\begin{array}{l}\text { Anlamlılık } \\
\text { Düzeyi } \\
\end{array}$} & \multirow[t]{2}{*}{ VIF } \\
\hline & B & Standart Hata & & & & \\
\hline (sabit) & 2,313 & 0,482 & & 4,800 & 0,000 & \\
\hline Toplumsal Fayda & 0,375 & 0,101 & 0,355 & 3,709 & 0,000 & 1,322 \\
\hline $\begin{array}{l}\text { Toplumsal } \\
\text { Maliyet }\end{array}$ & $-0,176$ & 0,096 & $-0,164$ & $\begin{array}{l}- \\
1,833\end{array}$ & 0,070 & 1,155 \\
\hline Motivasyon & 0,137 & 0,071 & 0,180 & 1,916 & 0,058 & 1,275 \\
\hline
\end{tabular}

Tablo 9'da Modele ait özet değerler incelendiğinde ANOVA anlamlılık değerinin 0,000 olduğu görülmektedir. Bu değer, 0,05 anlamlılık düzeyinde kurulan regresyon modelinin istatistiki açıdan anlamlı olduğunu ifade etmektedir. Düzeltilmiş $R^{2}$ değerinin 0,277 olduğu görülmektedir. Buna göre toplumsal fayda, toplumsal maliyet ve motivasyon değişkenleri, memnuniyet değişkenine ait toplam varyansın \%27,7'sini açılamaktadır. Kurulan regresyon modeline ait Durbin-Watson katsayısı 1,388'dir. 0 ile 4 arasında bir değer alabilen (Draper ve Smith, 1981: 299) bu katsayının 2'ye yaklaşması modelde oto korelasyon problemi olmadığını ifade etmektedir.

Toplumsal fayda değişkenine ait değerler incelendiğinde Beta katsayısının 0,375 olduğu ve bu katsayıya ait anlamlılık değerinin 0,000 olduğu görülmektedir. Buna göre toplumsal fayda değişkeninin 0,05 anlamlılık düzeyinde memnuniyet değişkeni üzerinde istatistiki açıdan anlamlı bir etkisi bulunmaktadır. Değişkene ait Beta katsayısının pozitif olması, toplumsal fayda değişkeninde meydana gelecek 1 birimlik artışın memnuniyet değişkeninde 
0,375 birimlik bir artışa neden olacağını ifade etmektedir. Sonuç olarak çalışmaya ait $\mathbf{H}_{1}$ hipotezi kabul edilmiştir.

Toplumsal maliyet bağımsız değişkeninin anlamlılık değeri 0,078 ve Beta katsayısı -0,176'dır. Toplumsal maliyet değişkeninin memnuniyet üzerindeki etkisi 0,05 düzeyinde istatistiki açıdan anlamlı değildir. 0,10 anlamlılık düzeyinde kabul edilebilir olsa da çalışma kapsamındaki istatistikler 0,05 düzeyinde değerlendirmeye tabii tutulduğundan $\mathbf{H}_{2}$ hipotezi reddedilmiştir.

Motivasyon değişkenine ait regresyon katsayılara bakıldığında anlamlılık değerinin 0,058 ve bu değişkene ait Beta katsayısının 0,137 olduğu görülmektedir. Bu değişkene ait anlamlılık katsayısı da 0,10 anlamlılık düzeyinde kabul edilebilecek $\mathrm{H}_{3}$ hipotezi reddedilmiştir.

Toplumsal fayda, toplumsal maliyet ve motivasyon bağımsız değişkenlerinin sadakat bağımlı değişkeni üzerindeki etkisinin incelendiği regresyon analizine ait katsayılar Tablo 10'da gösterilmektedir.

Tablo 10. Sadakat Bağımlı Değişkenine Ait Çoklu Regresyon Modeli Katsayılan

\begin{tabular}{|c|c|c|c|c|c|c|}
\hline \multicolumn{7}{|c|}{ Model Özeti: $R=0,660 / R^{2}=0,436 /$ Düzeltilmiş $R^{2}=0,419 / F=26,022 / p=0,00 /$ Durbin-Watson=1,388 } \\
\hline \multirow[t]{2}{*}{ MODEL } & \multicolumn{2}{|c|}{$\begin{array}{l}\text { Standardize Edilmemiş } \\
\text { Katsayılar }\end{array}$} & \multirow{2}{*}{$\begin{array}{l}\begin{array}{l}\text { Standardize Edilmiş } \\
\text { Katsayılar }\end{array} \\
\beta \\
\end{array}$} & \multirow[t]{2}{*}{$\mathrm{t}$} & \multirow[t]{2}{*}{$\begin{array}{l}\text { Anlamlılık } \\
\text { Düzeyi }\end{array}$} & \multirow[t]{2}{*}{ VIF } \\
\hline & $\mathrm{B}$ & Standart Hata & & & & \\
\hline (sabit) & 2,579 & 0,415 & & 6,217 & 0,000 & \\
\hline Toplumsal Fayda & 0,408 & 0,087 & 0,402 & 4,682 & 0,000 & 1,322 \\
\hline Toplumsal Maliyet & $-0,243$ & 0,083 & $-0,236$ & $-2,941$ & 0,004 & 1,155 \\
\hline Motivasyon & 0,159 & 0,061 & 0,219 & 2,592 & 0,011 & 1,275 \\
\hline
\end{tabular}

Toplumsal fayda, toplumsal maliyet ve motivasyon değişkenlerinin sadakat bağımlı değişkeni üzerindeki etkisini ölçmek üzere kurulan regresyon modelinin özet değerlerine bakıldığında ANOVA anlamlılık değerinin 0,00 olduğu gözlenmektedir. 0,05 anlamlılık düzeyinde kurulan modelin istatistiki açıdan anlamlı olduğu çıkarımı yapılabilmektedir. Düzeltilmiş $\mathrm{R}^{2}$ değeri ise 0,419 'dur. Bu değer, modeldeki bağımsız değişkenlerin sadakat değişkenine ait toplam varyansın \%41,9'unu açıkladığını ifade etmektedir. Modele ait Durbin-Watson katsayısı 1,388 olarak hesaplanmıştır ve bu değer modelde oto korelasyon sorunu olmadığını göstermektedir.

Modelde bağımsız değişken olarak yer alan toplumsal fayda değişkenine ait Beta katsayısı 0,408 ve anlamlılık değeri 0,00'dır. Toplumsal fayda değişkeninin sadakat üzerindeki etkisi 0,05 anlamlılık düzeyinde istatistiki açıdan anlamlıdır. Buna göre sadakat değişkeninde gerçekleşen 0,408 birimlik bir 
değişim toplumsal fayda değişkenindeki 1 birimlik değişimle mümkündür. Buradan hareketle $\mathbf{H}_{4}$ hipotezi kabul edilmiştir.

Toplumsal maliyet değişkenine ait Beta katsayısı -0,243 ve anlamlılık değeri 0,004'tür. Toplumsal maliyet değişkeninin sadakat değişkeni üzerindeki etkisi 0,05 anlamlılık düzeyinde istatistiki açıdan anlamlıdır. Toplumsal maliyetin sadakat üzerindeki etkisi negatif yönlüdür. Buna göre toplumsal maliyet değişkeninde gerçekleşecek 1 birimlik bir artışı sadakat değişkeninde 0,243 birimlik bir azalmaya neden olmaktadır. Sonuç olarak $\mathbf{H}_{5}$ hipotezi kabul edilmiştir.

Motivasyon değişkenine ait Beta katsayısı 0,159 ve anlamlılık değeri ise 0,011'dir. Kurulan regresyon modeline göre motivasyon değişkeninin sadakat üzerindeki etkisi istatistiki açıdan anlamlıdır. Buna göre sadakat değişkeninde gerçekleşecek 0,159 birimlik bir artış motivasyon değişkeninde gerçekleşebilecek 1 birimlik artış ile mümkündür. Buna göre $\mathbf{H}_{6}$ hipotezi kabul edilmiştir.

Tablo 11. Sadakat Bağımlı Değişkenine Ait Çoklu Regresyon Modeli Katsayılan

\begin{tabular}{|c|c|c|c|c|c|c|}
\hline \multicolumn{7}{|c|}{ Model Özeti: $R=0,825$ / R²= 0,681 / Düzeltilmiş $R^{2}=0,678$ / F= 219,567 / p= 0,00 / Durbin-Watson=1,362 } \\
\hline \multirow{3}{*}{ MODEL } & Stand & & Standardize & $\mathbf{t}$ & Anlamlılık & VIF \\
\hline & \multicolumn{2}{|c|}{ Edilmemiş Katsayılar } & Edilmiş Katsayılar & & Düzeyi & \\
\hline & $\mathrm{B}$ & Standart Hata & $\beta$ & & & \\
\hline (sabit) & 1,084 & 0,204 & & 5,317 & 0,000 & \\
\hline Memnuniyet & 0,792 & 0,053 & 0,825 & 14,818 & 0,000 & 1,000 \\
\hline
\end{tabular}

Memnuniyet değişkeninin sadakat değişkeni üzerindeki etkisini incelemek için kurulan regresyon modelinin özet değerleri incelendiğinde ANOVA anlamlılık düzeyinin 0,00 olduğu görülmektedir. Kurulan modelin 0,05 anlamlılık düzeyinde anlamlı olduğu sonucuna ulaşılmaktadır. Düzeltilmiş $R^{2}$ değerinin ise 0,681 olduğu görülmektedir. Bu model özelinde, sadakat değişkenine ait toplam varyansın \%67,8'i memnuniyet değişkeni tarafından açıklanabilmektedir. Modele ait Durbin-Watson katsayısı ise 1,362'dir ve değer modelde oto korelasyon sorunu olmadığını göstermektedir.

Memnuniyet değişkenine ait anlamlılık değeri 0,000 ve Beta katsayısı ise 0,792' dir. Buna göre memnuniyet değişkeninin sadakat değişkeni üzerindeki etkisi 0,05 düzeyinde istatistiki açıdan anlamlıdır. Memnuniyet değişkeninde gerçekleşecek 1 birimlik artış sadakat değişkeninde 0,792 birimlik bir artışa neden olmaktadır. Sonuç olarak $\mathbf{H}_{7}$ hipotezi kabul edilmiştir. 


\section{Sonuç}

İşletmeler turizm faaliyeti olan festivalleri, pazarlama ve halkla ilişkiler faaliyeti olarak görmektedir. Bu kapsamda işletmeler festivallere, müşterilerle temas kurmak ve ilişki geliştirmek, yeni pazarlama teknikleri deneyimlemek, yeni satış siparişleri almak ve müşterilerin ihtiyaçları hakkında bilgi edinmek gibi amaçlarla katılmaktadır. Bu çalışmada, Gönen Alışveriş Festivali incelenmiş ve festivalin paydaşı olan işletmelerin festivale ilişkin toplumsal fayda ve toplumsal maliyet algıları, festivale katılma motivasyonları, festivalden memnuniyet ve sadakat düzeyleri incelenmiştir. Yapılan analizler neticesinde, alg1lanan toplumsal faydanın memnuniyet ve sadakat üzerinde pozitif yönlü ve anlamlı etkisinin olduğu sonucuna varılmıştır. Bu sonuç geçmiş yıllarda yapılan çalışmaları destekleyici niteliktedir (Arcodia ve Whitford, 2007; Gursoy vd., 2004). Toplumsal maliyet değişkeninin sadakat üzerinde negatif yönlü ve anlamlı etkisi bulunurken (Delamere, 2001; Gossling, 2002) toplumsal maliyetin sadakat üzerindeki etkisi ise istatistiki açından anlamlı değildir. Bu sonuç Delamere vd. (2001) tarafından yapılan çalışmanın sonuçlarıyla çelişmektedir. Bu durum festivale katılan işletmelerin sonraki yıllarda yapılması planlanan festivallere yeniden katılımını ifade eden festivale olan sadakatlerinin algıladıkları toplumsal maliyet tarafından etkilenmediği şeklinde açıklanabilir. Kozak (2002) tarafından yapılan çalışmaya benzer şekilde, işletmelerin festivale katılma motivasyonlarının memnuniyet ve sadakat üzerinde pozitif yönlü ve anlamlı etkisinin olduğu bulunmuştur. Çalışmanın sonuçları ve öneriler aşağıda sıralanmaktadır. sonuçlar şu şekildedir:

İşletmelerin, festivalin satışlarını arttırıp arttırmadığına ilişkin değerlendirme ifadesine verdikleri cevapların ortalaması \%54,7' dir. Bu sonuç, festivalin paydaşı olan işletmelerin satışlarını arttırmak hususundaki beklentilerini tatmin edici düzeyde karşılamadığını göstermektedir. Buna göre, paydaşlar açısından önde gelen festivale katılım motivasyonlarından satış arttırmanın, sonraki festivallerde dikkat edilmesi gereken bir unsur olduğu ortaya çımaktadır. Festivalin paydaşı olan işletmelerin festival boyunca satışlarını artırabilmesi için organizatörlerin toplu ya da özelleştirilmiş satış promosyonları sunmak, organizatörler tarafından tüketicilere hediye çekleri vermek gibi satış destekleyici faaliyetleri organize etmesinin yararlı olabileceği düşünülmektedir. 
Festivalin tanıtımında kullanılan medya araçlarının (sosyal medya, yerel medya, ulusal medya) etkin kullanımına ilişkin değerlendirme ifadesine verilen cevapların ortalaması sosyal medya için \%65,3, yerel medya için $\% 55,1$ ve ulusal medya için $\% 28,2$ 'dir. Bu sonuçlara göre festivale katılan işletmelerin, ulusal medyanın etkin kullanılamadığına ilişkin yargıları bulunmaktadır. Bu hususta organizatörlerin, ilgili destinasyonda alısveriş festivali yapıldığına dair ana akım medya kuruluşlarını bilgilendirmesi hatta medya temsilcileri için konaklama imkanı sağlamak gibi kolaylaştırıcı ve teşvik edici faaliyetlerde bulunması önerilmektedir.

Araştırmanın uygulama aşamasında beş farklı ölçekten oluşan ve festivalin paydaşı işletmelere yöneltilen anket formuna verilen cevaplar incelendiğinde:

İşletmelerin, gerçekleştirilen bu festivale gelecek yıllarda tekrar katılımlaryyla ilgili görüşlerinin sorulduğu ifadeye verdiği cevapların ortalaması 4,14 olarak belirlenmiştir. Bu ortalama, cevaplayıcıların anket formunda yer alan ifadelere verdikleri cevaplar arasında en yüksek olanıdır. Buna göre paydaşların, festivalin tekrar düzenlenmesi durumunda yüksek oranda katılım niyetine sahip olduğu bulgusuna varılmıştır. Düzenlenmesi planlanan sonraki festivallerde satı̧s tutundurma faaliyetleri veya zenginleştirilmiş sosyal faaliyetler düzenlenerek paydaşların festivale katılım niyetleri de artırılabilir.

Toplumsal maliyet ölçeği içerisinde yer alan festivalin suç oranlarını arttırıp arttırmadığına ilişkin ifadeye verilen cevapların ortalaması 1,76' dır. Bu değer, anket formunda yer alan en düşük ortalamadır. Buradan hareketle, festivalin paydaşı işletmelerin suç oranlarının festivale bağlı olarak artmadı̆̆g görüşüne sahip olduğu sonucuna ulaşılmıştır. Öte yandan bu sonuç, festivalde alınan güvenlik önlemlerinin yeterliliği hakkındaki ifadeye ait \%69,7 oranıyla örtüşmektedir. Bu hususta organizatörlerin, hem kamusal kolluk kuvvetlerinden alınan desteği artırarak hem de özel güvenlik örgütlerinden hizmet alımı yaparak bu oranı yükseltebileceği düşünülmektedir.

Çalışmanın $\mathbf{H}_{\mathbf{1}}$ hipotezi kabul edilmiştir. Algılanan toplumsal faydanın memnuniyet üzerinde pozitif yönlü ve anlamlı bir ilişkisinin olduğu sonucuna ulaşılmıştır. Buna göre paydaşlar tarafından algılanan toplumsal fayda (festivalin sosyal ve ekonomik faydaları), memnuniyet düzeyine olumlu yönde güçlü bir etkisi bulunmaktadır. Burada organizatörlerin, paydaşların festival hakkındaki genel memnuniyet düzeyini arttırmak için toplumsal fayda unsurlarına daha çok önem vermeleri gerektiği sonucuna varılabilir. 
Öte yandan paydaşların festivale ilişkin algıladığı toplumsal maliyet ve katılım motivasyonunun genel memnuniyet düzeyi üzerinde bir etkisinin olmadiğı görülmüştür.

Toplumsal faydanın, sadakat üzerinde güçlü etkisi olduğu sonucuna ulaşılmıştır. Festivallerdeki toplumsal fayda unsurları, festivale dair sadakat tutumu sergilenmesine önemli katkıda bulunmaktadır. Dolayısıyla daha sonra düzenlenmesi planlanan festivallere paydaşların yeniden katılımı ve devamlılığ için sosyal etkileşim, kent imajının çekiciliği, işletmelerin ve/veya kentin tanıtımı gibi unsurlar organizatörler tarafından özellikle dikkate alınmalıdır.

$\mathbf{H}_{5}$ hipotezine dair bulgulara bakıldığında algılanan toplumsal maliyetin, festivale olan sadakati olumsuz yönde etkilediği görülmektedir. Yani paydaşların, festivalden algıladıkları toplumsal maliyet düzeyi arttıkça festivale duydukları sadakat düzeyi azalmaktadır. Bu sonuç Crompton (1995) tarafından yapılan araştırmayı destekleyici niteliktedir. Buradan hareketle organizatörler festivallerden algılanan toplumsal maliyeti azaltmak amacıyla çeşitli düzenlemeler ve iyileştirmeler (güvenlik, trafik, çevre ve rekabet düzenlemeleri) yapması önerilebilir.

Festivale katılma motivasyonunun sadakat üzerindeki etkisinin olduğu sonucuna ulaşılmıştır. Bu sonuca göre işletmeler pazar bilgisi topladığında, satışlarını arttırdığında veya tanıtım imkânı yakaladığında işletmelerin sadakat düzeyinin arttığı ifade edilebilir. Paydaşların sadakat düzeyini arttırmayı amaçlayan organizatörlerin, paydaşların bahsedilen motivasyonlarına odaklanması gerektiği düşünülmektedir. Festival paydaşı işletmelerin nihai tüketiciler ile satış öncesinde de irtibat kurabilmesi, halkla ilişkiler faaliyetlerini yürütebilmesi veya ürünlerini tanıtabilmesi için işletmelerin kendi fiziki alanları dışında standlar veya tanıtım noktaları kurabilmesine organizatörlerce olanak sağlanabilir.

Son olarak paydaşların algıladığı memnuniyet düzeyinin sadakat üzerinde olumlu bir etkisi bulunmaktadır. Paydaşların, düzenlenmesi planlanan sonraki festivallere katılımını ve sadakat düzeylerini arttırmak için paydaşlara tatmin ve mutlu olacağ memnuniyet düzeyinin arttırılacağı sonucuna ulaşılabilir. Paydaşların genel memnuniyetini artırmak yoluyla düzenlenmesi planlanan sonraki organizasyonlara katılma isteğini artırmak için organizatörler, daha falza nihai tüketicinin festival katılımını teşvik edebilir veya paydaş işletmelerin satış tutundurma faaliyetlerine kurumsal olarak destek verebilir. 
Festivallerin paydaşları ve organizatörler için yukarıda sıralanan önerilerin yanı sıra bu alanda çalışmalarını yürüten araştırmacılara sunulabilecek öneriler şu şekildedir:

$\mathrm{Bu}$ araştırma kapsamında incelenen bağımlı ve bağımsız değişkenlere literatüre uygun; çevresel atmosfer, festival kalitesi, festivalden beklenen memnuniyet şeklinde farklı boyutlar biçimde ekleme veya çıarma yapılarak çalışmalar çeşitlendirilebilir.

Ayrıca, araştırmacılar tarafından farklı örneklem ile örnek olay incelemesi yapılabilir. Festival öncesinde paydaşların beklenti düzeylerini belirlemek için saha çalışmaları ve bunu takiben festival sonrasında da memnuniyet düzeyinin belirlenmesi gibi ölçümler gerçekleştirilebilir. Daha verimli ve etkin bir ölçüm için eş zamanlı olarak daha geniş coğrafya ve katılımcı sayısı ile saha çalışmaları yapılabilir. 


\title{
EXTENDED ABSTRACT
}

\section{Examining the Effects of Perceived Social Benefit, Perceived Social Cost and Participation Motivation in The Festival on Satisfaction and Loyalty}

\author{
Orhan Duman - Sertaç Ercan - Burak Yaprak \\ Bandırma Onyedi Eylul University
}

Festivals, which are tourism marketing and management activities are economic, social and cultural events aimed at making positive contributions to destinations. In this study, Gönen Shopping Festival, which was held for the first time in 2019, was considered as a sample event, and it was aimed to determine the social benefits and social costs of the festivals, the motivations of the stakeholders to participate in the festival, and the festival satisfaction and festival.

The universe of the study research consists of firms from various sectors located around the festival area in the city center, where the shopping festival held in the Gönen District of Balıkesir in Turkey on November 21-22-23, 2019. If a survey application or similar techniques are applied to all units that make up the research universe, there is a complete count. The sample of this study consists of 105 companies in total upon the guidance of the Gönen Chamber of Commerce, which is the organizer of the festival.

According to Table 1, \%27.6 (29 companies) of the all companies that responded to the survey form employed one person, \%34.3 (36) employed two people, and \%9.5 (10) employed three people. Thus, a total of \%71.4 (75) of responsive companiess can be defined as micro-companies. Out of these companies, $\% 10.5$ (11) were run by four people, $\% 2.9$ (3) employed five, and \%14.3 (16) were run by six or more people. In terms of the core business of these companies, \%26.7 (28), 1-5 years, \%20.9 percent (19) 6-10 years, \%12.4 (13), 1115 years, $\% 13.3(14), 16-20$ years, $\% 8.5$ (8), $21-25$ years, and $18.2 \%$ (12) of companies continued its activities for more than 25 years. It shows that the vast majority of responsive companies are old companies of the region. 


\begin{tabular}{lllll}
\hline Hypothesis & Hypothesis Statement & $\boldsymbol{\beta}$ & Sig. & Status \\
\hline $\mathbf{H}_{\mathbf{1}}$ & Social benefit has a significant effect on satisfaction. & 0,375 & 0,000 & Supported \\
\hline $\mathbf{H}_{2}$ & Social cost has a significant effect on satisfaction. & 0,176 & 0,078 & Rejected \\
\hline $\mathbf{H}_{3}$ & Motivation has a significant effect on satisfaction. & 0,137 & 0,058 & Rejected \\
\hline $\mathbf{H}_{4}$ & Social benefit has a significant effect on loyalty. & 0,408 & 0,000 & Supported \\
\hline $\mathbf{H}_{5}$ & Social cost has a significant effect on loyalty. & $-0,243$ & 0,004 & Supported \\
\hline $\mathbf{H}_{6}$ & Motivation has a significant effect on loyalty. & 0,159 & 0,011 & Supported \\
\hline $\mathbf{H}_{7}$ & Satisfaction has a significant effect on loyalty. & 0,792 & 0,000 & Supported \\
\hline
\end{tabular}

The $\mathbf{H}_{1}$ hypothesis of the study is suppot. Accordingly, the social benefit (social and economic benefits of the festival) perceived by the stakeholders has a strong positive effect on the satisfaction level. It can be concluded that organizers should give more importance to social benefit elements in order to increase the overall satisfaction of the stakeholders about the festival. The $\mathbf{H}_{2}$ and $\mathbf{H}_{3}$ hypotheses of the study are rejected. Based on this, it was seen that the social cost perceived by the stakeholders and the motivation to participate in the festival had no effect on the general satisfaction level.

$\mathbf{H}_{4}, \mathbf{H}_{5}$ and $\mathbf{H}_{6}$ hypotheses of the study are supported. The effect of social utility tested by $\mathbf{H}_{4}$ hypothesis on loyalty is quite strong. Social benefit elements in festivals contribute significantly to displaying the attitude of loyalty towards the festival. Therefore, factors such as social interaction, the attractiveness of the city image, the promotion of the companies and / or the city should be taken into consideration by the organizers for the re-participation and continuity of the stakeholders in the festivals planned to be held later. Considering the findings of the $\mathbf{H}_{5}$ hypothesis, it is seen that the perceived social cost negatively affects the loyalty to the festival. In other words, as the social cost perceived by the stakeholders from the festival increases, their level of loyalty to the festival decreases. From this point of view, organizers may be suggested to make various arrangements and improvements (safety, traffic, environment and competition regulations) in order to reduce the social cost perceived from festivals. $\mathbf{H}_{\mathbf{6}}$ hypothesis, which measures the effect of motivation to participate in the festival on loyalty, is supported as a result of the analysis. According to this result, it can be stated that the loyalty level of the companies increases when they collect market information, increase their sales or get the opportunity of promotion. It is considered that organizers aiming to increase the level of loyalty of the stakeholders should focus on the mentioned motivations of the stakeholders. 
The last hypothesis of the study, $\mathbf{H}_{7}$, is supported. Accordingly, the level of satisfaction perceived by stakeholders has a positive effect on loyalty. It can be concluded that the overall satisfaction level of the festival will be increased by offering the stakeholders experiences that will be satisfied and happy in order to increase the participation and loyalty of the stakeholders in the next festivals planned to be held.

Consequently, companies consider festivals that are tourism activities as marketing and public relations activities. In this context, companies participate in festivals for purposes such as contacting and developing relationships with customers, experiencing new marketing techniques, receiving new sales orders and obtaining information about customers' needs. In this study, a case study is conducted and the social benefit and social cost perceptions of the companies that are the stakeholders of the festival, their motivation to participate in the festival, their satisfaction and loyalty levels are examined. The results are as follows:

The average of the answers given by the companies to the evaluation statement on whether the festival has increased their sales or not is $54.7 \%$. This result shows that the companies, which are the stakeholders of the festival, did not satisfactorily meet their expectations about increasing their sales. Accordingly, it appears that increasing sales, which is one of the leading motivation for participating in the festival, is an element to be considered in the following festivals. The average of the responses given to the evaluation statement regarding the effective use of media tools (social media, local media, national media) used in the promotion of the festival is $65.3 \%$ for social media, $55.1 \%$ for local media and $28.2 \%$ for national media. According to these results, companies participating in the festival have judgments that the national media is not used effectively. In addition to the suggestions listed above for the stakeholders and organizers of the festivals, the suggestions that can be presented to the researchers working in this field are 1) Studies can be diversified by adding or removing the dependent and independent variables examined within the scope of this research, in accordance with the literature, 2) Case studies can be conducted by researchers with different samples, 3) Measurements such as field studies to determine the expectation levels of the stakeholders before the festival, followed by determination of the satisfaction 
level after the festival can be made. For a more efficient and effective measurement, field studies can be carried out simultaneously with a wider geography and number of participants.

\section{Kaynakça / References}

Allen, J., O'Toole, W., McDonnell, I. ve Harris, R. (2012). Festival and special event management. Milton John Wiley \& Sons Inc.

Andereck, K. L., Valentine, K. M., Knopf, R. C. ve Vogt, C. A. (2005). Residents' perceptions of community tourism impacts. Annals of Tourism Research, 32(4), 10561076.

Anderton, C. (2011). Music festival sponsorship: Between commerce and carnival. Arts Marketing, 1(2), 145.

Arcodia, C. ve Whitford, M. (2007). Festival Attendance and the development of social capital. Paper Presented at The Journal of Convention \& Event Tourism.

Attanasi, G., Casoria, F., Centorrino, S. ve Urso, G. (2013). Cultural investment, local development and instantaneous social capital: A case study of a gathering festival in the South of Italy. The Journal of Socio-Economics, 47, 228-247.

Backman, K. F., Backman, S. J., Uysal, M. ve Sunshine, K. M. (1995). Event tourism: An examination of motivations and activities. Festival Management and Event Tourism, 3(1), 15-24.

Báez, A. ve Devesa, M. (2014). Segmenting and profiling attendees of a film festival. International Journal of Event and Festival Management, 5(2), 96-115.

Besculides, A., Lee, M. E. ve McCormick, P. J. (2002). Residents' perceptions of the cultural benefits of tourism. Annals of Tourism Research, 29(2), 303-319.

Carlsen, J., Ali-Knight, J. ve Robertson, M. (2007). Access: A research agenda for Edinburgh Festivals. Event Management, 11(1-2), 3-11.

Chen, $\mathrm{C}$, ve Li, X. (2020). The effect of online shopping festival promotion strategies on consumer participation intention. Industrial Management $\mathcal{E}$ Data Systems.

Crompton, J. L. (1995). Economic impact analysis of sports facilities and events: Eleven sources of Misapplication. Journal of Sport Management, 9(1), 14-35.

Çalışkan, O. (2013). Restoran İşletmelerinde hizmet hataları, hizmet telafi stratejileri ve müşteri memnuniyeti ilişkisi. Seyahat ve Otel İsletmeciliüi Dergisi, 10(3).

Delamere, T. A. (2001). Development of a scale to measure resident attitudes toward the social impacts of community festivals, Part II. Verification of the scale. Event Management, 7(1), 25-38. 
Delamere, T. A., Wankel, L. M. ve Hinch, T. D. (2001). Development of a scale to measure resident attitudes toward the social impacts of community festivals, Part I: Item generation and purification of the measure. Event Management, 7(1), 1124.

Draper, N.R. veH. Smith, (1981). Applied regression analysis. 2. ed., New York: John Wiley \& Sons.

Dura, C. (2005). Düşünme, araştırma ve yazma yöntemleri. Kayseri: Ekin Kitabevi.

Ferdinand, N. ve Williams, N. L. (2013). International Festivals as Experience Production Systems. Tourism Management, 34, 202-210.

Fredline, L., Raybould, M., Jago, L. ve Deery, M. (2005). Triple bottom line event evaluation: A proposed framework for holistic event evaluation. Paper Presented at The International Event Research Conference, Sydney, Australia: Australian Centre for Event Management.

Gale, F. (1997). Direct farm marketing as a rural development tool. Rural America/Rural Development Perspectives, 12(2221-2019-2615), 19-25.

Gegez, E. (2010). Pazarlama araştırmaları. Beta Yayınları.

Getz, D. (1993). Festivals and Special Events (Ed. M. A. Khan, O. M. D., et al. V. T. (Eds.)), Encyclopedia of hospitality and tourism. New York: Van Nostrand Reinhold.

Getz, D. (2005). Event management $\mathcal{E}$ event tourism. (2nd ed.), New York: Cognizant Communication Corporation.

Gössling, S. (2002). Global environmental consequences of tourism. Global Environmental Change. 12(4), 283-302.

Graf, A. ve Maas, P. (2008). Customer value from a customer perspective: A comprehensive review. Journal Für Betriebswirtschaft, 58(1), 1-20.

Grunwell, S. (2007). Film festivals: An empirical study of factors for success. Event Management, 11(4), 201-210.

Gursoy, D., Kim, K. ve Uysal, M. (2004). Perceived Impacts of festivals and special events by organizers: An extension and validation. Tourism Management, 25(2), 171-181.

Hair, J. F., Bush, R. P. ve Ortinau, D. J. (2000). Marketing research: A practical approach for the new millennium. Irwin Professional Publishing.

Irshad, H. (2011). Impacts of community events and festivals on rural places, Government of Alberta, Agriculture and Rural Development Division.

Kim, H., Borges, M. C. ve Chon, J. (2006). Impacts of environmental values on tourism motivation: The case of Fica, Brazil. Tourism Management, 27(5), 957-967.

Kim, K. ve Uysal, M. (2003). Perceived Socio-economic Impacts of Festivals and Events Among Organizers. Journal of Hospitality E Leisure Marketing, 10(3-4), 159-171. 
Kozak, M. (2002). Comparative analysis of tourist motivations by nationality and destinations. Tourism Management, 23(3), 221-232.

Kozak, N. (2005). The expectations of exhibitors in tourism, hospitality, and the travel industry: A case study on East Mediterranean tourism and travel exhibition. In Journal of Convention \& Event Tourism, 7(3-4), 99-116.

Lee, J. S., ve Back, K. J. (2008). Attendee-based brand equity. Tourism Management, 29(2), 331-344.

Lee, J. S., Lee, C. K. ve Choi, Y. (2011). Examining the role of emotional and functional values in festival evaluation. Journal of Travel Research, 50(6), 685-696.

Lee, J., ve Beeler, C. (2006). The relationships among quality, satisfaction, and future intention for first-time and repeat visitors in a festival setting. Event Management, 10(4), 197-208.

O'Sullivan, D. ve Jackson, M. J. (2002). Festival tourism: A contributor to sustainable local economic development?. Journal of Sustainable Tourism, 10(4), 325-342.

Oliver, R. L. (1980). A cognitive model of the antecedents and consequences of satisfaction decisions. Journal of Marketing Research, 17(4), 460-469.

Pirnar, I., Kurtural, S., ve Tutuncuoglu, M. (2019). Festivals and destination marketing: An application from Izmir City. Journal of Tourism, Heritage \& Services Marketing, 5(1), 9-14.

Polat, Ş.B. (2012). Yükseköğretim kurumlarnda kurum içi iletişim anlayışı ve paydaş memnuniyeti ilişkisi: Akademik personel perspektifinde bir çalş̧ma. İstanbul: Maltepe Üniversitesi Sosyal Bilimler Enstitüsü.

Quinn, B. (2006). Problematising 'festival tourism': Arts Festivals and sustainable development in Ireland. Journal of Sustainable Tourism, 14(3), 288-306.

Saayman, M., Kruger, M. ve Erasmus, J. (2012). Finding the key to success: A visitors' perspective at a national arts festival. Acta Commercii, 12(1), 150-172.

Sasser, W. E., Schlesinger, L. A. ve Heskett, J. L. (1997). Service profit chain. Simon and Schuster.

Uysal, M., Gahan, L. ve Martin, B. (1993). An examination of event motivations: A case study. Festival Management and Event Tourism, 1(1), 5-10.

Walo, M., Bull, A. ve Breen, H. (1996). Achieving economic benefits at local events: A case study of a local sports event. Festival Management and Event Tourism, 4(34), 95-106.

Woosnam, K. M., Van Winkle, C. M. ve An, S. (2013). Confirming the festival social mpact attitude scale in the context of a rural Texas Cultural Festival. Event Management, 17(3), 257-270. 
Yazıcı, T., Kocak, S., ve Altunsöz, I. H. (2017). Examining the effect of experiential marketing on behavioral intentions in a festival with a specific sport event. European Sport Management Quarterly, 17(2), 171-192.

Yeoman, I., Robertson, M., Ali-Knight, J., Drummond, S. ve McMahon-Beattie, U. (2012). Festival and events management. Routledge.

Yolal, M., Çetinel, F. ve Uysal, M. (2009). An examination of festival motivation and perceived benefits relationship: Eskişehir International Festival. Paper presented at the Journal of Convention \& Event Tourism.

Yolal, M., Gursoy, D., Uysal, M., Kim, H. L. ve Karacaoğlu, S. (2016). Impacts of festivals and events on residents' well-being. Annals of Tourism Research, 61, 1-18.

Yolal, M., Woo, E., Cetinel, F. ve Uysal, M. (2012). Comparative research of motivations across different festival products. International Journal of Event and Festival Management, 3(1), 66-80.

Yoo, C. W., Sanders, G. L. ve Moon, J. (2013). Exploring the effect of e-wom participation on e-loyalty in e-commerce. Decision Support Systems, 55(3), 669-678.

Yoon, Y.-S., Lee, J.-S. ve Lee, C.K. (2010). Measuring festival quality and value affecting visitors' satisfaction and loyalty using a structural approach. International Journal of Hospitality Management, 29(2), 335-342.

\section{Kaynakça Bilgisi / Citation Information}

Duman, O., Ercan, S., ve Yaprak, B.(2021). Festival katılımcısı işletmelerin algilanan toplumsal fayda, algilanan toplumsal maliyet ve katılım motivasyonlarının festival memnuniyeti ve sadakati üzerindeki etkisi. OPUS-Uluslararası Toplum Araştırmaları Dergisi, 17(35), 2125-2154. DOI: 10.26466/opus.815382 